Marquette University

e-Publications@Marquette

School of Dentistry Faculty Research and

Publications

Dentistry, School of

$1-2018$

\title{
The Efficacy of Commercial Tooth Storage Media for Maintaining the Viability of Human Periodontal Ligament Fibroblasts
}

W. Lee

Marquette University

Sheila E. Stover

Marquette University

Morteza Rasoulianboroujeni

Marquette University

K. Sherman

Marquette University

Farahnaz Fahimipour

Marquette University

See next page for additional authors

Follow this and additional works at: https://epublications.marquette.edu/dentistry_fac

Part of the Dentistry Commons

\section{Recommended Citation}

Lee, W.; Stover, Sheila E.; Rasoulianboroujeni, Morteza; Sherman, K.; Fahimipour, Farahnaz; Dashtimoghadam, E.; Zito, C.; Jazayeri, Hossein E.; and Tayebi, Lobat, "The Efficacy of Commercial Tooth Storage Media for Maintaining the Viability of Human Periodontal Ligament Fibroblasts" (2018). School of Dentistry Faculty Research and Publications. 296.

https://epublications.marquette.edu/dentistry_fac/296 


\section{Authors}

W. Lee, Sheila E. Stover, Morteza Rasoulianboroujeni, K. Sherman, Farahnaz Fahimipour, E. Dashtimoghadam, C. Zito, Hossein E. Jazayeri, and Lobat Tayebi 
Marquette University

\section{e-Publications@Marquette}

\section{Dentistry Faculty Research and Publications/College of Dentistry}

This paper is NOT THE PUBLISHED VERSION; but the author's final, peer-reviewed manuscript. The published version may be accessed by following the link in th citation below.

International Endodontic Journal, Vol. 51, No. 1 (January 2018): 58-68. DOI. This article is (C) International Endodontic Journal. Published by John Wiley \& Sons Ltd and permission has been granted for this version to appear in e-Publications@Marquette. International Endodontic Journal. Published by John Wiley \& Sons Ltd does not grant permission for this article to be further copied/distributed or hosted elsewhere without the express permission from International Endodontic Journal. Published by John Wiley \& Sons Ltd.

\section{The Efficacy of Commercial Tooth Storage Media for Maintaining the Viability of Human Periodontal Ligament Fibroblasts}

W. Lee

Department of Surgical Services, School of Dentistry, Marquette University, Milwaukee, WI

S. Stover

Department of Surgical Services, School of Dentistry, Marquette University, Milwaukee, WI

M. Rasoulianboroujeni

Department of Developmental Sciences, School of Dentistry, Marquette University, Milwaukee, WI

K. Sherman

Department of Mathematics, Statistics and Computer Science, Marquette University, Milwaukee, WI

F. Fahimipour

Department of Developmental Sciences, School of Dentistry, Marquette University, Milwaukee, WI Dental Biomaterials Department, School of Dentistry, Tehran University of Medical Sciences, Tehran, Iran 


\section{E. Dashtimoghadam}

Department of Developmental Sciences, School of Dentistry, Marquette University, Milwaukee, WI

\section{Zito}

Department of Developmental Sciences, School of Dentistry, Marquette University, Milwaukee, WI

H. E. Jazayeri

Department of Developmental Sciences, School of Dentistry, Marquette University, Milwaukee, WI

L. Tayebi

Department of Developmental Sciences, School of Dentistry, Marquette University, Milwaukee, WI

\section{Abstract}

\section{Aim}

To evaluate Save-A-Tooth (SAT), EMT Toothsaver (EMT) and Hank's Balanced Salt Solution (HBSS) for their influence on the viability and proliferative capacity of human periodontal ligament fibroblasts (HPDLFs).

\section{Methodology}

Primary HPDLFs were seeded into 96-well cell culture plates and exposed to SAT, EMT, HBSS and water (negative control) for $0.5,1,3,6,12$ and $24 \mathrm{~h}$ at room temperature $\left(22^{\circ} \mathrm{C}\right)$. After each exposure time, cell viability was measured through quantifying adenosine triphosphate (ATP) using a luminescent dye. The proliferative capacity was also quantified using the PrestoBlue assay after 12 or $24 \mathrm{~h}$ storage in each medium. The data were analysed statistically by two-way anova and post hocLeast Significant Difference (LSD) test $(P<0.05)$. The morphology of the cells after $12 \mathrm{~h}$ storage was also investigated through live/dead viability/cytotoxicity kit together with fluorescence microscopy.

\section{Results}

There was no significant difference in cell viability amongst HBSS, SAT and EMT groups up to $6 \mathrm{~h}$. SAT was effective in maintaining cell viability only up to $12 \mathrm{~h}$ and then became detrimental to HPDLF; after $24 \mathrm{~h}$, the effectiveness of SAT in maintaining cell viability was similar to that of water $(P>0.05)$. Amongst all the media, only EMT could maintain the proliferative capacity of HPDLFs significantly higher than the negative control, that is water $(P<0.05)$ after $24 \mathrm{~h}$ storage.

\section{Conclusion}

EMT maintained the proliferative capacity of HPDLFs after $24 \mathrm{~h}$ storage.

\section{Introduction}

Tooth avulsion is the complete displacement of a tooth from its alveolar socket due to a traumatic injury (American Academy of Pediatric Dentistry 2008). The reported incidence rate of the tooth avulsion ranges from $0.5 \%$ to $9 \%$ of all dental trauma in the permanent dentition (Andersson et al. 2006, Andreasen \& Andreasen 2007). Traffic accidents, falls and participation in sports have been reported to be the three most frequent incidents that lead to the avulsion of incisors in children (Petrovic et al. 2010).

According to clinical guidelines, an avulsed tooth must be appropriately pre-conditioned and ultimately replanted into the alveolar socket (Mclntyre et al. 2009). The most significant and prevalent complication after replantation is external root resorption, particularly replacement resorption, preceded by ankylosis (Andreasen \& Hjorting-Hansen 1966, Andreasen et al. 1995, Kinirons et al. 1999, Chappuis \& von Arx $\underline{2005}$, Werder et al. 2011). One of the most critical prognostic factors is the viability of PDL cells at the time of replantation (Löe \& Waerhaug 1961, Andreasen et al. 1995), which, in turn, depends on the extra-alveolar dry 
time (Soder et al. 1977, Andreasen 1981). The duration of extra-alveolar dry storage, therefore, has a direct impact on the prognosis of the replanted tooth, as demonstrated by numerous studies (Cvek et al. 1974 , Andreasen 1981, Andreasen \& Kristerson 1981 Matsson et al. 1982, Trope \& Friedman 1992 , Andreasen et al. 1995, Chappuis \& von Arx 2005, Werder et al. 2011).

The most favourable condition for survival of the avulsed tooth is achieved by immediate replantation (Andreasen \& Hjorting-Hansen 1966, Trope \& Friedman 1992, Andreasen et al. 1995). However, immediate replantation is not always possible due to fear or lack of knowledge (Glendor 2009, Merz et al. 2011, Emerich \& Nadolska-Gazda 2013). Management of concomitant injuries may also delay the replantation of an avulsed tooth (Petrovic et al. 2010). The avulsed tooth, when it cannot be replanted immediately, must be stored in a suitable storage medium until it can be replanted in order to prevent damage to PDL cells due to dehydration. Delayed replantation following nonphysiological storage leads to a high chance of root resorption and tooth loss (Petrovic et al. 2010). It has been suggested that a tooth storage medium should maintain viability as well as clonogenic and mitogenic capacity of PDL cells, have physiological osmolality and pH, induce no antigenantibody reaction, and demonstrate antimicrobial activity (Malhotra 2011).

Household items such as milk could be considered as a practical medium for short-term storage of an avulsed tooth due to its availability (McIntyre et al. 2009). Milk has a physiological pH and osmolality values of 6.7 and $277 \mathrm{mOsm} \mathrm{kg}^{-1}$, respectively (Marino et al. 2000). Animal studies have demonstrated that tooth storage in milk for up to $6 \mathrm{~h}$ resulted in periodontal healing with a low incidence of root resorption after replantation (Blomlöf et al. 1983, Trope \& Friedman 1992). However, extended periods of preservation might be achieved using Hank's Balanced Salt Solution (HBSS), the standard storage medium for an avulsed tooth (Flores et al. 2007, Andersson et al. 2012), or commercial products.

Save-A-Tooth (SAT) (Phoenix-Lazerus, Inc., Shartlesville, PA, USA) and EMT Toothsaver (EMT) (SmartPractice.com, Phoenix, AZ, USA) are two commercially available tooth storage media.

Whilst SAT is a HBSS-based solution, EMT is made of Special Cell Culture Medium (SCCM), which is a modified version of Roswell Park Memorial Institute (RPMI) medium that contains special preservatives (Pohl et al. 1999). EMT is marketed as Dentosafe (MEDICE Arzneimittel Pütter GmbH \& Co. KG, Iserlohn, Germany) in Europe.

The aim of this study was to compare SAT and EMT with HBSS, as the standard storage medium, for their respective effects on the viability and proliferative capacity of human periodontal ligament fibroblasts (HPDLFs) over time using a highly sensitive ATP assay and PrestoBlue assay, respectively. The null hypothesis is that all the storage media are the same in maintaining the viability and proliferative capacity of HPDLFs and they are as detrimental to cells as water is at all time-points.

\section{Materials and Methods}

This research experimental design using HPDLFs was approved by the Graduate School, Marquette University (Milwaukee, WI, USA), and an exemption status was granted by the Institutional Review Board of Marquette University.

\section{Determination of $\mathrm{pH}$ and osmolality}

Sterile HBSS with calcium and magnesium (Mediatech Inc., Herndon, VA, USA), SAT and EMT were purchased and stored in accordance with the manufacturers' instructions. For each tooth storage medium, HBSS and deionized water, $\mathrm{pH}$ level and osmolality values were measured using a SevenExcellence $\mathrm{pH}$ Meter (Mettler Toledo, Columbus, OH, USA) and a Vapro model 5600 Vapor Pressure Osmometer (EliTech Group, Princeton, NJ, USA), respectively. 


\section{Culture of human periodontal ligament fibroblasts}

Primary HPDLFs were purchased from ScienCell Research Laboratories (Carlsbad, CA, USA). ScienCell Research Laboratories Inc. isolates the cells from human periodontal tissue. HPDLFs are cryopreserved at passage one and delivered frozen with a density of $5 \times 10^{5}$ cells per $\mathrm{mL}$. The cells were thawed upon receipt and transferred to cell culture flasks to grow. The cells were incubated in Eagle's minimum essential medium supplemented with $10 \%$ foetal bovine serum (Mediatech Inc), 1\% penicillin (10000 units $\mathrm{mL}^{-1}$ ) and streptomycin (10000 $\mu \mathrm{g} \mathrm{mL}^{-1}$ ) (Quality Biological Inc, Gaithersburg, MD, USA), 1\% amphotericin $\left(250 \mu \mathrm{g} \mathrm{mL}^{-1}\right.$ ) (Amresco LLC, Solon, OH, USA) and $5 \mathrm{mM} \mathrm{L-Glutamine} \mathrm{(Amresco,} \mathrm{Solon,} \mathrm{OH,} \mathrm{USA)} \mathrm{(EMEM-FBS-PS-A-L)} \mathrm{at} 37^{\circ} \mathrm{C}$ in a humidified atmosphere of $5 \% \mathrm{CO}_{2}$ and $95 \%$ air. The HPDLFs were refed with fresh media every 3-4 days and incubated until the cells reached approximately $90 \%$ confluency. Once fibroblast-like phenotypes of the cells were confirmed under a microscope, the HPDLFs were trypsinized using TrypLE ${ }^{\mathrm{TM}}$ Express Enzyme (Invitrogen, Carlsbad, CA, USA) and then subcultured.

\section{Exposure of cells to tooth storage media}

The cells of the third passage were used for the experiment. The HPDLFs were trypsinized and resuspended in the prepared media. The number of cells were counted via trypan blue exclusion method, and the HPDLFs were seeded into 96 -well cell culture plates, with a density of $5 \times 10^{3}$ cells per well. After 24 -hour incubation at $37^{\circ} \mathrm{C}$ in $5 \% \mathrm{CO} 2$, the cell culture medium in each well was replaced with $100 \mu \mathrm{L}$ of one of the following media: HBSS, SAT, EMT or deionized water (negative control). The HPDLFs were then incubated at room temperature $\left(22^{\circ} \mathrm{C}\right)$ for $0.5,1,3,6,12$ or $24 \mathrm{~h}$.

\section{Assessment of cell viability using an ATP assay}

At the end of each exposure time, the viability of HPDLFs were determined through quantifying the detectable ATP, using CellTiter-Glo ${ }^{\circledR}$ luminescent cell viability assay (Promega Co., Madison, WI, USA). $100 \mu \mathrm{L}$ of CellTiter$\mathrm{Glo}^{\circledR}$ Reagent was added to each well, followed by incubation at room temperature for $10 \mathrm{~min}$ to stabilize the luminescent signal. The luminescent signal for each sample was measured in the form of Relative Light Unit (RLU) using a SynergyHTX Multi-Mode Reader (BioTek Instruments, Inc., Winooski, VT, USA).

\section{Serial dilution}

To correlate the actual number of metabolically active cells with the obtained luminescent signal value, CellTiter-Glo ${ }^{\circledR}$ luminescent cell viability assay was run with serially diluted nontreated cells, from 10000 to 0 cells per well.

\section{Assessment of viability and post-storage proliferation capacity of HPDLFs using}

\section{PrestoBlue assay}

To validate the viability measurement of HPDLF cells through ATP assay over time, and evaluation of poststorage proliferation capacity of the cells, the PrestoBlue assay was used. For this purpose, the same cell density, incubation temperature and exposure protocol were used as described previously. The complete cell culture media containing DMEM supplemented with $10 \% \mathrm{FBS}$ at $37^{\circ} \mathrm{C}$ and $5 \% \mathrm{CO}_{2}$ were used as the control. For viability assessment, the storage media, that is water, EMT, HBSS or SAT were replaced by $150 \mu \mathrm{L}$ of $10 \%(\mathrm{v} / \mathrm{v})$ PrestoBlue solution in phenol red-free DMEM after 3,12 and $24 \mathrm{~h}$, the plates were incubated at $37^{\circ} \mathrm{C}$ for $30 \mathrm{~min}$, and the change in the fluorescent signal was recorded using a SynergyHTX Multi-Mode Reader (BioTek Instruments, Inc., Winooski, VT, USA) at excitation/emission wavelengths of 560/590 nm.

Furthermore, the PrestoBlue assay was used to examine the proliferative capacity of HPDLF cells stored in various media for 12 and $24 \mathrm{~h}$. For this purpose, each storage medium was replaced by the complete cell culture media (DMEM supplemented with 10\% FBS) after 12 or 24 h, and the cells were allowed to proliferate in cell 
culture medium at $37^{\circ} \mathrm{C}, 5 \% \mathrm{CO}_{2}$ for 24 and $48 \mathrm{~h}$. After the desired time, the cell culture media were replaced by $150 \mu \mathrm{L}$ of $10 \%(\mathrm{v} / \mathrm{v})$ PrestoBlue solution in phenol red-free DMEM, and again change in the fluorescent signal was recorded at 560/590 nm excitation/emission wavelengths after incubation at $37^{\circ} \mathrm{C}$ for $30 \mathrm{~min}$.

Figure $\underline{1}$ schematically represents the PrestoBlue assay protocol.

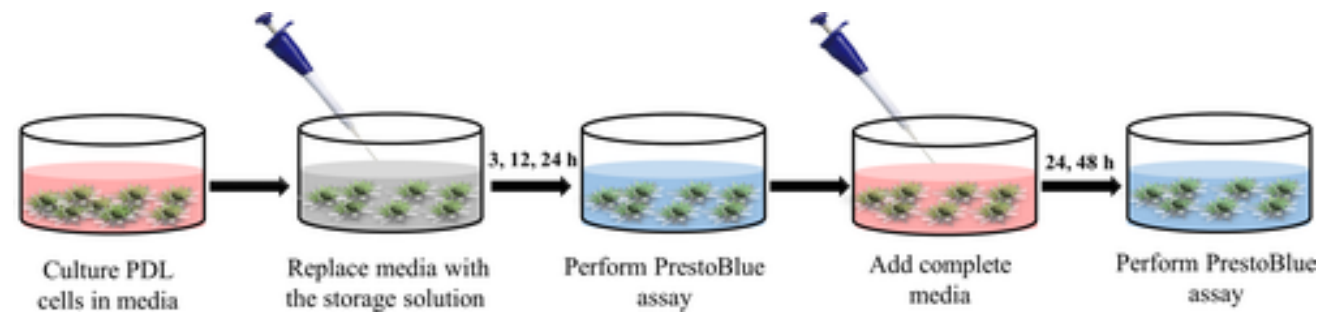

Figure 1 Schematic representation of PrestoBlue assay protocol used to measure cell viability after 3, 12 and $24 \mathrm{~h}$ and post-storage proliferative capacity after 12 or $24 \mathrm{~h}$ exposure to storage media.

\section{Live/dead staining}

Viability and morphology of HPDLF cells were also determined by live/dead staining. In brief, after $12 \mathrm{~h}$ of introducing storage media to the HPDLF cells, they were stained by adding NucBlue Live (DAPI filter) and NucGreen ${ }^{\circ}$ Dead (GFP filter) reagents (Thermo Fisher, Waltham, MA, USA) with the ratio of $1: 100$ to the cell culture media. After incubation for 15 min, imaging was carried out using a fluorescence microscope (EVOS FL, Life Technologies, Carlsbad, CA, USA). Using this method of staining, the nuclei of all the cells turn blue, whilst the nuclei of the dead cells present a green fluorescence emission. To observe the morphology of the cells, fluorescein sodium salt aqueous solution was directly added to the cells already stained by live/dead kit (total concentration of $150 \mu \mathrm{g} \mathrm{mL}^{-1}$ ) to stain the cytoplasm of the cells.

\section{Statistical analysis}

Statistical analysis of the data was accomplished using IBM SPSS Statistics Version 23 (SPSS In., Chicago, IL, USA). A two-way anovawas used to analyse the effects of different media and storage time on cell viability; Fisher's Least Significant Difference (LSD) was used for post hoc analysis. $P$-values less than 0.05 were considered significant.

\section{Results}

\section{Osmolality and $\mathrm{pH}$ of media}

The osmolality and $\mathrm{pH}$ values of all tested media are summarized in Table $\underline{\underline{1}}$. The osmolality of HBSS, SAT and EMT was within the physiological range. The osmolality of deionized water was $0 \mathrm{mOsmol} \mathrm{kg}{ }^{-1}$. SAT had the osmolality of $295 \mathrm{mOsmol} \mathrm{kg}{ }^{-1}$, which was within the optimal range for cell growth. The osmolality of EMT and HBSS was 331 and $279 \mathrm{mOsmol} \mathrm{kg}{ }^{-1}$, respectively. These values were well within the osmolality range in which cell growth would occur. The pH levels of EMT were the closest to the physiological level, followed by HBSS, SAT and water.

Table 1. Values of $\mathrm{pH}$ and osmolality of HBSS, SAT, EMT and water used in this study

\begin{tabular}{|l|l|l|}
\hline Sample & $\mathbf{p H}$ & Osmolality $\left(\mathbf{m O s m o l ~}_{\mathbf{~ k}} \mathbf{- 1}\right)$ \\
\hline HBSS & 8.021 & 279 \\
\hline SAT & 6.568 & 295 \\
\hline EMT & 7.3 & 331 \\
\hline Water & 6.193 & 0 \\
\hline
\end{tabular}




\section{Luminescent signal and cell count}

A linear relationship $\left(r^{2}=0.987\right)$ was observed between the luminescent signal obtained by CellTiter-

Glo luminescent cell viability assay and the number of cells from 0 to 10000 cells per well. The luminescent signal from $5 \times 10^{3}$ HPDLFs were greater than 700 times the background signal from medium without any cells.

\section{Comparison of cell viability amongst different media groups}

The results of the metabolically active viable cells at different time-points in each medium are shown in Fig. $\underline{\mathbf{2}}$ a. Furthermore, the variation in the number of viable cells as a function of time of storage in each medium has been indicated in Fig. $\underline{2} b$.

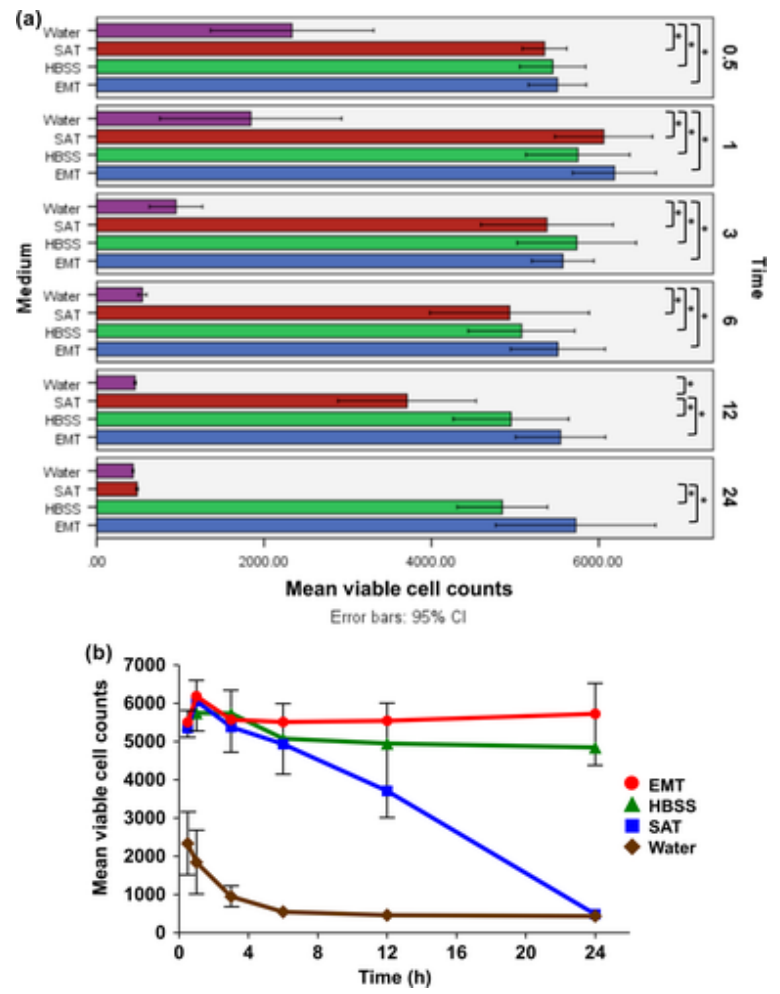

Figure 2 Average number of viable cells in different media (water, SAT, HBSS and EMT) after 0.5, 1, 3, 6, 12 and $24 \mathrm{~h}$ storage measured using ATP assay $(a, b)$. The number of viable cells has been presented as means and standard deviations ( $95 \%$ confidence intervals). An overall alpha-level of 0.05 was used as a cut-point for statistical significance.

A significant difference in viability of the cells existed amongst tested media when compared over all time-points $(P<0.05)$. The HPDLFs in EMT had the highest number of viable cells, followed by HBSS and SAT. The cells treated with water had the lowest rate of viability overall. Each of these differences was statistically significant $(P<0.05)$. At the 0.5-, 1-, 3- and 6-hour time-points, the number of viable HPDLFs in water was significantly lower $(P<0.05)$ than those in EMT, HBSS and SAT, amongst which no significant difference was observed.

After $12 \mathrm{~h}$ of exposure, considerably lower numbers of viable cells were observed in the SAT group compared to EMT and HBSS groups; the viability of SAT-treated cells was still significantly higher than water $(P<0.05)$, however. There was no significant difference between EMT and HBSS groups at this time-point.

At the 24- hour time-point, no significant difference existed between the number of viable HPDLFs in SAT and water. EMT and HBSS maintained approximately the same luminescent signal strength, which represents the metabolically active viable cells, until the $24^{\text {th }}$ hour. The signal strength from the SAT group decreased significantly between 6 - and 12 -hour time-points and again between 12 - and 24-hour time-points $(P<0.05)$. 
Within the water group, the highest values of luminescence occurred at 0.5 - and 1-hour time-points. The remainder of the time-points had statistically similar luminescence signal values, which were significantly lower than those at the 0.5 - and 1-hour time-points $(P<0.05)$.

PrestoBlue assay at 3, 12 and $24 \mathrm{~h}$ confirmed the superiority of EMT over SAT (Fig. $\underline{3}$ ) at all time-points $(P<0.05)$. HBSS also performed significantly better than SAT for up to $12 \mathrm{~h}(P<0.05)$. However, no significant difference was overserved between HBSS and SAT after $24 \mathrm{~h}$ when PrestoBlue assay was used.

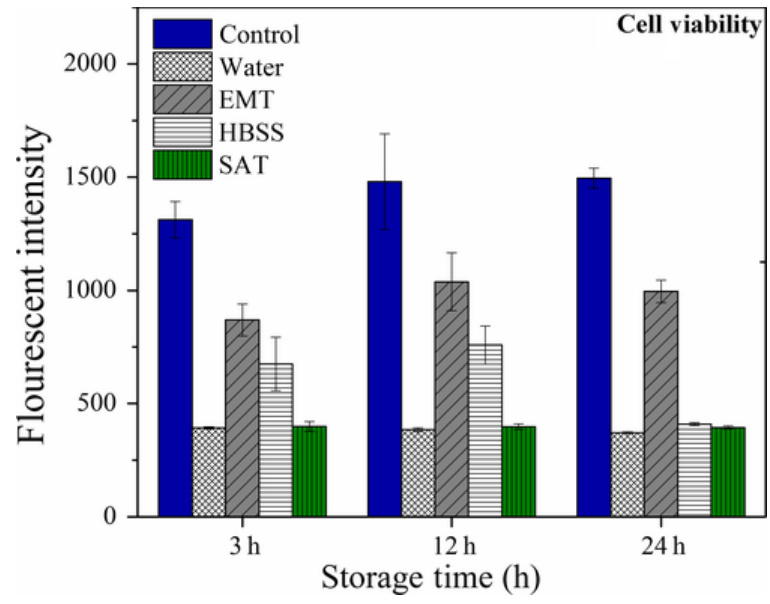

Figure 3 Viability of HPDLFs stored in different media for 3, 12 or 24 h; PrestoBlue assay has been used.

\section{Post-storage proliferative capacity of HPDLFs}

Figure $\underline{4}$ shows the proliferative capacity of HPDLFs after exposure to each storage media for 12 or $24 \mathrm{~h}$. As can be seen, amongst all the media only EMT maintained the proliferative activity of the cells after $24 \mathrm{~h}$ storage. EMT performance after $24 \mathrm{~h}$ storage was significantly better than SAT, HBSS and water $(P<0.05)$ whereas the efficiency of the latter media had no significant difference. Whilst cells stored in HBSS represent a small poststorage activity after $12 \mathrm{~h}$ storage, prolonging the storage to $24 \mathrm{~h}$ eliminates their proliferative capacity. Cells stored in SAT did not reveal any proliferative activity independent of the length of storage time. The performance of EMT, HBSS and SAT was significantly different from each other after $12 \mathrm{~h}$ storage $(P<0.05)$ amongst which EMT and SAT represented the superior and inferior efficiencies, respectively.
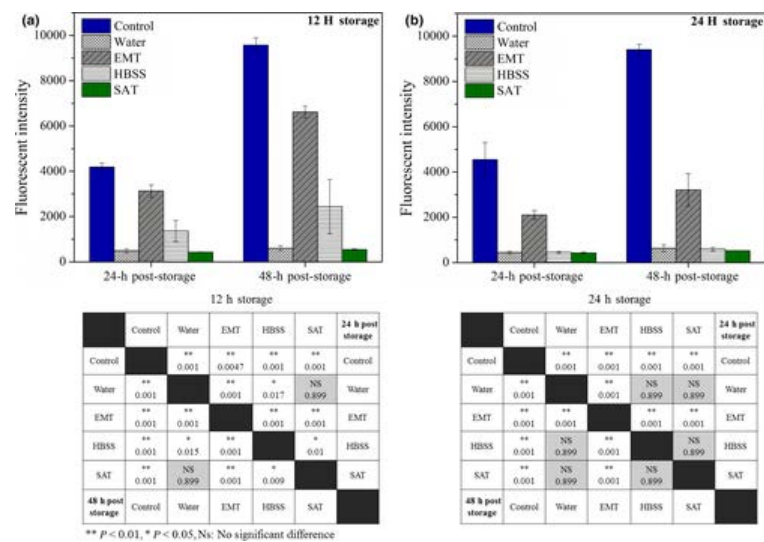

Figure 4 Post-storage proliferative capacity of HPDLFs stored for 12 (a) or 24 (b) hours in each medium. Statistical analysis was performed for each two groups, and an overall alpha-level of 0.05 was used as a cut-point for statistical significance. 


\section{Live/dead staining}

Figure $\underline{\mathbf{5}}$ shows the live/dead staining results along with the morphology of HPDLFs. EMT and HBSS successfully preserved the cells up to $12 \mathrm{~h}$ (blue nuclei) whilst the major fraction of the cells stored in water and SAT were dead (green nuclei). The cells exposed to EMT and HBSS maintained their spindle-like morphology whilst storage in water led to round cells with no anchoring power. Interestingly, even though the cells stored in SAT were metabolically inactive, they maintained their spindle-like morphology.

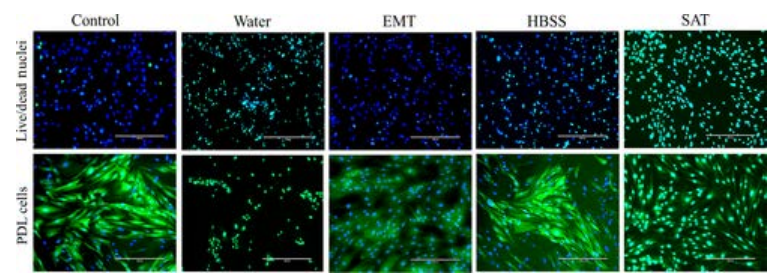

Figure 5 Live/dead and fluorescein staining of the HPDLFs stored in each medium for $12 \mathrm{~h}$; green nuclei show the dead cells while. The spindle-like morphology can be seen for all the samples except water.

\section{Discussion}

In the present study, the effect of water, HBSS, SAT and EMT as the storage media for an avulsed tooth on HPDLF cell viability, proliferative capacity and morphology was investigated. Whilst using a storage medium that can maintain the viability of PDL cells prior to replantation is an important prognostic factor, there are other factors that can affect the outcome of replantation including extra-alveolar dry time prior to transferring the tooth to the storage media or the time the tooth is out of its socket, possible bacterial contamination, patient's general health and the maturity of the root (Savas et al. 2015).

The number of viable, metabolically active HPDLFs were determined by quantifying detectable ATP with the CellTiter-Glo luminescent cell viability assay. The kit contains luciferase, which reacts with ATP extracted from metabolically active cells to generate a luminescent signal as a by-product. The advantage of using this method for cell viability measurement over the widely used trypan blue exclusion test is that it can characterize the metabolic condition of the cells, enabling this research study to be more clinically relevant. In comparison, the trypan blue exclusion test can only discriminate cells with intact or damaged plasma membranes.

Ashkenazi et al. (Ashkenazi et al. 2000) proved that the clinical functionality of the storage media did not correlate with the viability assessed by the trypan blue exclusion test.

In this study, a known number of viable, active HPDLFs were serially diluted, and the assay was used to correlate the intensity of the obtained luminescent signal to the number of cells. The obtained linear correlation $\left(r^{2}=0.987\right)$ indicates that the amount of ATP, represented by the luminescent signal, is directly proportional to the number of metabolically active cells. This is in agreement with a previous report (Crouch et al. 1993) and the manufacturer's claim.

The results of this study suggest that EMT and HBSS are more effective and superior to SAT when HPDLFs have to be stored and preserved for an extended period of time as they can maintain the viability, proliferative capacity and morphology of these cells more efficiently. HBSS is sterile and contains essential nutrients (Hiltz \& Trope 1991). Having a physiological pH (7.2-7.4) (Krasner \& Person 1992, Khademi et al. 2008, Mousavi et al. 2010, Hwang et al. 2011) and osmolality (275-284 $\mathrm{mOsm} \mathrm{kg}^{-1}$ ) (Blomlof et al. 1981, Khademi et al. 2008, Mousavi et al. 2010, Hwang et al. 2011), HBSS is suitable for cell survival and growth (Waymouth 1970). Several studies have shown that HBSS can preserve the viability of PDL cells for an extended period of time (Ashkenazi et al. 2000, Hwang et al. 2011); promote proliferation (Sigalas et al. 2004); and maintain high mitogenicity of PDL cells (Ashkenazi et al. 2000). HBSS is also beneficial to those PDL cells that are initially stored in a dry condition (Pileggi et al. 2002, Caglar et al. 2010, Mahal et al. 2013) or in saliva 
(Lekic et al. 1998). The main drawback of HBSS as a tooth storage medium is its limited availability to the public at or near the site where tooth avulsion occurs (Sigalas et al. 2004). Although HBSS is commonly recommended as a clinical storage solution for avulsed teeth, its ability for the long-term preservation of cells has not been accepted. HBSS storage on the other hand results in failure of the solution to adequately nourish the cells for more than $6 \mathrm{~h}$ perhaps because of changes in the concentration of its components (Moura et al. 2014). The SAT is a HBSS-based system and consists of a sealed container and a suspension net that protects the avulsed tooth once it is dropped into the system (Krasner \& Person 1992). SAT has a pH of 6.4-7.2 (Marino et al. 2000, Souza et al. 2010a) and osmolality of $275 \mathrm{mOsm} \mathrm{kg}^{-1}$ (Marino et al. 2000). Several studies, however, have found that SAT is inferior to HBSS in preserving the viability of PDL cells (Souza et al. 2010a, $\underline{\mathbf{b}}, \underline{2011}$ ), and it is as detrimental to PDL cells as water after $24 \mathrm{~h}$ at room temperature (Souza et al. $2010 \mathrm{a}, \underline{\mathbf{b}}$ ) or $72 \mathrm{~h}$ at $5{ }^{\circ} \mathrm{C}$ (Souza et al. 2011). EMT on the other hand has demonstrated a healing rate of $75 \%$ when used to store avulsed teeth before replantation (Pohl et al. 2005a, $\underline{\mathbf{b}} \underline{\mathbf{c}}$, Werder et al. 2011). An in vitro study has demonstrated that SCCM maintained proliferative activity of PDL cells for up to $48 \mathrm{~h}$ (Pohl et al. 1999).

The present results indicate that water had a detrimental effect on the viability of the HPDLF after only 30 min of storage; less than a half of the total number of cells survived after $30 \mathrm{~min}$, and by $24 \mathrm{~h}$ less than $9 \%$ of the cells were viable. Pure water has a hypotonic osmolality with 3-4 mOsm kg ${ }^{-1}$ (Marino et al. $\underline{2000}$ ) and causes cell damage and lysis (Blomlof et al. 1981). Replanting avulsed teeth stored in tap water resulted in a high incidence rate of replacement resorption (Andreasen 1981). Water, therefore, is considered as the least favourable tooth storage medium (Trope 2002) and should be avoided (Andersson et al. 2012). Most studies on tooth storage media use water as the negative control for this reason.

The detrimental effect of SAT on the HPDLFs after $24 \mathrm{~h}$ agrees with previous studies (Souza et al. 2010a, $\underline{\mathbf{b}}$, 2011). It was found that the effect of SAT on the HPDLFs were similar to that of water after $24 \mathrm{~h}$ of storage at $20^{\circ} \mathrm{C}$ (Souza et al. 2010a, $\underline{\text { b) }}$ and $37^{\circ} \mathrm{C}$ (Souza et al. 2010a) or after $72 \mathrm{~h}$ at $5{ }^{\circ} \mathrm{C}$ (Souza et al. 2011).

Despite similarities between the components of HBSS and SAT (Krasner \& Person 1992), HBSS successfully maintained the viability of the HPDLFs throughout the observation period, whilst SAT was not effective after $6 \mathrm{~h}$ of storage. Souza et al. (2010a, 2011) also found that SAT constantly performed inferiorly to HBSS, regardless of the storage temperature, sterility (Souza et al. 2010a) or freshness (Souza et al. 2010b) of the media after a short storage times. The authors suggested that such disparities between the two media might be attributed to

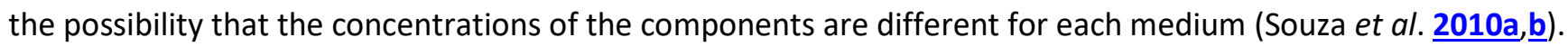
To verify this statement, the formulation of HBSS that was used to make the Emergency Tooth Preserving System, which was later renamed SAT, was cross-referenced with the documented formulations of regular HBSS from three different distributors and manufacturers (Thermo Fisher Scientific Inc., Sigma-Aldrich Co. LLC. and Mediatech Inc.) (Krasner et al. 1989). Indeed, some differences in components and concentrations amongst the different versions of HBSS and SAT were noted (Krasner \& Person 1992). These differences could potentially explain why SAT was not able to maintain the viability of the HPDLF as efficiently as HBSS in the present study. Further investigations are necessary to confirm this hypothesis and determine whether or not it would have a clinical impact.

In addition to the existence of vital PDL cells, maintaining proliferative capacity is decisive for periodontal healing following replantation (Pohl et al. 2005b). Both EMT (Pohl et al. 1999, 2005b) and HBSS

(Blomlof et al. 1981, Harkacz et al. 1997, Ashkenazi et al. 2001) have been shown to maintain vitality and proliferative capacity (high mitogenicity) of PDL cells for extended periods at room temperature in vitro. This is in agreement with the results in the present study and could be attributed to the composition of these storage media, that is different salts, amino acids, vitamins and glucose in the formulation (Pohl et al. 2005c). 
The effect of osmolality of media on cell survival and growth has been demonstrated in numerous studies (Waymouth 1970, Andreasen 1981, Blomlof et al. 1981, Lindskog \& Blomlöf 1982). Whilst cells can grow in media with an osmolality in the range of $230-400 \mathrm{mOsm} \mathrm{kg}^{-1}$, a more optimal rate of cell growth has been observed in media with an osmolality in the range of 290-330 mOsm kg-1 (Waymouth 1970). Lindskog \& Blomlöf (1982) tested the viability of PDL cells stored in sucrose solutions in various concentration: Only $10 \%$ of the cells remained viable in the hypotonic sucrose solution, whilst $35 \%$ of cells survived in the sucrose solution with a physiological osmolality. The results of this study emphasize a critical influence of the osmolality of storage media to cell viability.

The osmolality analysis in this study showed that all the media, except for deionized water, had physiological osmolality values. Deionized water had an osmolality of $0 \mathrm{mOsmol} \mathrm{kg}{ }^{-1}$, which explains the detrimental effect on the HPDLFs during the experiment. The results showed that the HPDLFs stored in SAT and water had a similarly low viability after $24 \mathrm{~h}$. This implicates that, at least for long-term storage, other features of media, such as electrolyte and nutrient concentration, may be more closely linked to viability of the HPDLFs than osmolality is. This is supported by others (Marino et al. 2000, Hwang et al. 2011). Marino et al. (2000) showed that both long shelf-life milk and regular pasteurized milk outperformed SAT in protecting the HPDLFs, in spite of their similarity in osmolality. Hwang et al. (2011) found that green tea extract, with osmolality of $138 \mathrm{mOsmol} \mathrm{kg}^{-1}$, had better ability to maintain the HPDLF viability than HBSS or milk.

All the experiments in this study were performed at room temperature. However, one may note the effect of storage temperature on the viability of PDL cells. Schwartz et al. (2002) investigated the effect of temperature $\left(-18,4,22,37^{\circ} \mathrm{C}\right)$ on periodontal and pulpal healing after replantation of incisors in monkeys. They concluded that the storage temperature (above $0{ }^{\circ} \mathrm{C}$ ) is important only for dry storage for short extra-alveolar periods, where extensive destruction of the PDL always takes place by evaporation.

\section{Conclusion}

Within the limitation of this study, for long-term storage of an avulsed tooth (6-24 h), EMT and HBSS are more effective than SAT. SAT was effective only for $6 \mathrm{~h}$, at which point it started losing its efficacy and became as detrimental to HPDLFs as water by the $24^{\text {th }}$ hour.

\section{Acknowledgements}

The authors wish to thank Delta Dental for the financial support, Dr. Naveen Bansal for his help with statistical analysis, Dr. Dawei Liu for helping with cell cultures and Dr. Sunyoung Park for her proofreading of this manuscript.

\section{Conflict of Interest}

The authors have stated explicitly that there are no conflict of interests in connection with this article.

\section{References}

American Academy of Pediatric Dentistry (2008) Guideline on management of acute dental trauma. Pediatric Dentistry 30, 175-83.

Andersson L, Al-Asfour A, Al-Jame Q (2006) Knowledge of first-aid measures of avulsion and replantation of teeth: an interview of 221 Kuwaiti schoolchildren. Dental Traumatology 22, 57-65.

Andersson L, Andreasen JO, Day P et al. (2012) International Association of Dental Traumatology guidelines for the management of traumatic dental injuries: 2 . Avulsion of permanent teeth. Dental Traumatology 28, 88-96. 
Andreasen JO (1981) Effect of extra-alveolar period and storage media upon periodontal and pulpal healing after replantation of mature permanent incisors in monkeys. International Journal of Oral Surgery 10, 43- 53.

Andreasen J, Andreasen F (2007) Textbook and color atlas of traumatic injuries to the teeth, 4th edn. Copenhagen: Wiley-Blackwell.

Andreasen JO, Hjorting-Hansen E (1966) Replantation of teeth. I. Radiographic and clinical study of 110 human teeth replanted after accidental loss. Acta Odontologica Scandinavica 24, 263- 86.

Andreasen JO, Kristerson L (1981) The effect of limited drying or removal of the periodontal ligament: periodontal healing after replantation of mature permanent incisors in monkeys. Acta Odontologica Scandinavica 39, 1- 13.

Andreasen J, Borum MK, Jacobsen H, Andreasen F (1995)Replantation of 400 avulsed permanent incisors. 4. Factors related to periodontal ligament healing. Dental Traumatology 11, 76- 89.

Ashkenazi M, Marouni M, Sarnat H (2000) In vitro viability, mitogenicity and clonogenic capacity of periodontal ligament cells after storage in four media at room temperature. Dental Traumatology 16, 63- 70.

Ashkenazi M, Marouni M, Sarnat H (2001) In vitro viability, mitogenicity and clonogenic capacities of periodontal ligament fibroblasts after storage in four media supplemented with growth factors. Dental Traumatology 17, 27- 35.

Blomlof L, Otteskog P, Hammarstrom L (1981) Effect of storage in media with different ion strengths and osmolalities on human periodontal ligament cells. European Journal of Oral Sciences 89, 180- 7.

Blomlöf L, Lindskog S, Andersson L, Hedström K-G, Hammarström L(1983) Storage of experimentally avulsed teeth in milk prior to replantation. Journal of Dental Research 62, 912-6.

Caglar E, Sandalli N, Kuscu O et al. (2010) Viability of fibroblasts in a novel probiotic storage media. Dental Traumatology 26, 383- 7.

Chappuis V, von Arx T (2005) Replantation of 45 avulsed permanent teeth: a 1-year follow-up study. Dental Traumatology 21, 289- 96.

Crouch S, Kozlowski R, Slater K, Fletcher J (1993) The use of ATP bioluminescence as a measure of cell proliferation and cytotoxicity. Journal of Immunological Methods 160, 81- 8.

Cvek M, Granath L-E, Hollender L (1974) Treatment of non-vital permanent incisors with calcium hydroxide. 3. Variation of occurrence of ankylosis of reimplanted teeth with duration of extra-alveolar period and storage environment. Odontologisk Revy 25, 43- 56.

Emerich K, Nadolska-Gazda E (2013) Dental trauma, prevention and knowledge concerning dental first-aid among Polish amateur boxers. Journal of Science and Medicine in Sport 16, 297- 301.

Flores MT, Andersson L, Andreasen JO et al. (2007) Guidelines for the management of traumatic dental injuries. II. Avulsion of permanent teeth. Dental Traumatology 23, 130-6.

Glendor U (2009) Has the education of professional caregivers and lay people in dental trauma care failed? Dental Traumatology 25, 12-8.

Harkacz OM, Carnes DL, Walker WA (1997) Determination of periodontal ligament cell viability in the oral rehydration fluid Gatorade and milks of varying fat content. Journal of Endodontics 23,687- 90.

Hiltz J, Trope M (1991) Vitality of human lip fibroblasts in milk, Hanks balanced salt solution and Viaspan storage media. Dental Traumatology 7, 69- 72.

Hwang JY, Choi SC, Park J-H, Kang SW (2011) The use of green tea extract as a storage medium for the avulsed tooth. Journal of Endodontics 37, 962- 7.

Khademi A, Saei S, Mohajeri M, Mirkheshti N, Ghassami F (2008) A new storage medium for an avulsed tooth. Journal of Contemporary Dental Practice 9, 25- 32.

Kinirons M, Boyd D, Gregg T (1999) Inflammatory and replacement resorption in reimplanted permanent incisor teeth: a study of the characteristics of 84 teeth. Dental Traumatology 15, 269- 72.

Krasner P, Person P (1992) Preserving Avulsed Teeth for Replantation. The Journal of the American Dental Association 123, 80- 8. 
Krasner P, Rankow H, Ehrenreich A (1989) Apparatus for storing and transporting traumatically avulsed teeth. Compendium (Newtown, Pa.)10, 232- 7.

Lekic P, Kenny D, Barrett E (1998) The influence of storage conditions on the clonogenic capacity of periodontal ligament cells: implications for tooth replantation. International Endodontic Journal 31, 137- 40.

Lindskog S, Blomlöf L (1982) Influence of osmolality and composition of some storage media on human periodontal ligament cells. Acta Odontologica Scandinavica 40, 435- 42.

Löe H, Waerhaug J (1961) Experimental replantation of teeth in dogs and monkeys. Archives of Oral Biology 3, 176- 84.

Mahal N, Singh N, Thomas A, Kakkar N (2013) Effect of three different storage media on survival of periodontal ligament cells using collagenase-dispase assay. International Endodontic Journal 46,365- 70.

Malhotra N (2011) Current developments in interim transport (storage) media in dentistry: an update. British Dental Journal 211,29- 33.

Marino TG, West LA, Liewehr FR et al. (2000) Determination of periodontal ligament cell viability in long shelflife milk. Journal of Endodontics 26, 699- 702.

Matsson L, Andreasen J, Cvek M, Granath L (1982) Ankylosis of experimentally reimplanted teeth related to extra-alveolar period and storage environment. Pediatric Dentistry 4, 327-9.

McIntyre JD, Lee JY, Trope M, Vann J, William F (2009) Permanent tooth replantation following avulsion: using a decision tree to achieve the best outcome. Pediatric Dentistry 31, 137- 44.

Merz M, Krastl G, Kühl S, Filippi A (2011) A survey of Swiss swimming pool attendants' knowledge of first-aid treatment after lip and dental injuries. Schweizer Monatsschrift fur Zahnmedizin 121, 528-44.

Moura CCG, Soares PBF, Reis P et al. (2014) Potential of coconut water and soy milk for use as storage media to preserve the viability of periodontal ligament cells: an in vitro study. Dental Traumatology30, 22-6.

Mousavi B, Ali Alavi S, Reza Mohajeri M, Mirkheshti N, Ghassam F, Mirkhesht N (2010) Standard oral rehydration solution as a new storage medium for avulsed teeth. International Dental Journal 60,379-82.

Petrovic B, Marković D, Peric T, Blagojevic D (2010) Factors related to treatment and outcomes of avulsed teeth. Dental Traumatology 26,52-9.

Pileggi R, Dumsha TC, Nor JE (2002) Assessment of post-traumatic PDL cells viability by a novel collagenase assay. Dental Traumatology18, 186- 9.

Pohl Y, Tekin U, Boll M, Filippi A, Kirschner H (1999) Investigations on a cell culture medium for storage and transportation of avulsed teeth. Australian Endodontic Journal 25, 70- 5.

Pohl Y, Filippi A, Kirschner H (2005a) Results after replantation of avulsed permanent teeth. I. Endodontic considerations. Dental Traumatology 21, 80-92.

Pohl Y, Filippi A, Kirschner H (2005b) Results after replantation of avulsed permanent teeth. II. Periodontal healing and the role of physiologic storage and antiresorptive-regenerative therapy. Dental Traumatology 21, 93-101.

Pohl Y, Wahl G, Filippi A, Kirschner H (2005c) Results after replantation of avulsed permanent teeth. III. Tooth loss and survival analysis. Dental Traumatology 21, 102- 10.

Savas S, Kucukyilmaz E, Akcay M, Koseoglu S (2015) Delayed replantation of avulsed teeth: Two case reports. Case Reports in Dentistry. 2015, 1-5.

Schwartz O, Andreasen F, Andreasen J (2002) Effects of temperature, storage time and media on periodontal and pulpal healing after replantation of incisors in monkeys. Dental Traumatology 18, 190- 5.

Sigalas E, Regan JD, Kramer PR, Witherspoon DE, Opperman LA(2004) Survival of human periodontal ligament cells in media proposed for transport of avulsed teeth. Dental Traumatology 20, 21-8.

Soder P, Otteskog P, Andreasen J, Modeer T (1977) Effect of drying on viability of periodontal membrane. European Journal of Oral Sciences 85, 164- 8.

Souza BDM, Lückemeyer DD, Felippe WT, Simões CMO, Felippe MCS(2010a) Effect of temperature and storage media on human periodontal ligament fibroblast viability. Dental Traumatology 26,271- 5. 
Souza BDMD, Bortoluzzi EA, Da Silveira Teixeira C, Felippe WT, Simões CMO, Felippe MCS (2010b) Effect of HBSS storage time on human periodontal ligament fibroblast viability. Dental Traumatology26, 481- 3.

Souza B, Lückemeyer D, Reyes-Carmona J, Felippe W, Simões C, Felippe M (2011) Viability of human periodontal ligament fibroblasts in milk, Hank's balanced salt solution and coconut water as storage media. International Endodontic Journal 44, 111- 5.

Trope M (2002) Clinical management of the avulsed tooth: present strategies and future directions. Dental Traumatology 18, 1- 11.

Trope M, Friedman S (1992) Periodontal healing of replanted dog teeth stored in Viaspan, milk and Hank's balanced salt solution. Dental Traumatology 8, 183-8.

Waymouth C (1970) Osmolality of mammalian blood and of media for culture of mammalian cells. In Vitro Cellular \& Developmental Biology-Plant 6, 109- 27.

Werder P, von Arx T, Chappuis V (2011) Treatment outcome of 42 replanted permanent incisors with a median follow-up of 2.8 years. Schweizer Monatsschrift fur Zahnmedizin 121, 312- 20. 